\title{
Science Fiction Collections in ARL Academic Libraries
}

\section{Kevin P. Mulcahy}

\begin{abstract}
This study assesses the extent to which ARL academic libraries collect science fiction novels. A core list of 200 novels, published between 1950 and 2000, that have either won science fiction awards or been cited on "best" lists were checked against the holdings of 112 ARL libraries. Findings suggest that science fiction is not extensively collected at most libraries studied. The study also assesses differences in how novels are collected by date and by nationality and gender of author. To support in-depth and serious research in a field of increasing scholarly interest, libraries may need to reconsider their collecting practices.
\end{abstract}

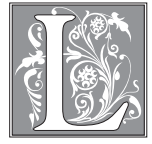

ike a number of popular literature genres, science fiction has attracted increasing attention from academic scholars and critics over the past three decades. Academic interest in science fiction has increased because of a general interest in popular culture, but also because of the enormous popularity of science fiction films and the pervasive impact on our society of technological advances once restricted to the imagination of science fiction writers, including personal computers, the Internet, cloning, and high-tech weapons systems. Scholarly attention is reflected in the number of science fiction courses offered at colleges and universities (more than 400 according to a 1996 study $^{1}$ ) and the emergence of several academic journals dedicated to the critical study of science fiction, including Extrapolation, Science Fiction Studies, and Foundation. Attention is further manifested by the proliferation of science fiction scholarship and history published by presses catering to the academic market (for example,
Contributions to the Study of Science Fiction and Fantasy from Greenwood Press and Liverpool Science Fiction Texts and Studies from Liverpool University Press) and a number of scholarly series reprinting classics of science fiction literature (for example, Wesleyan Early Classics of Science Fiction from Wesleyan University Press and Bison Frontiers of Imagination from the University of Nebraska Press). The Science Fiction Research Association (founded in 1970) is just one of several scholarly associations with a specific interest in the field.

However, many science fiction writers and scholars fear that the field is still relegated to the margins of the accepted literary canon, especially as manifested in academic teaching, criticism, and publishing. Both a collection of essays entitled Science Fiction, Canonization, Marginalization, and the Academy and the introduction to a May 2004 special issue of PMLA titled "Science Fiction and Literary Studies: The Next Millennium" argue for the importance of science fiction but also

Kevin P. Mulcahy is the English and American Literature Librarian in Alexander Library at Rutgers University; e-mail: Mulcahy@rci.rutgers.edu. 
express anxiety and frustration over what many science fiction scholars perceive as continuing academic neglect. ${ }^{2}$ And almost any academic involved in science fiction teaching or scholarship will have firsthand experience of colleagues' scorn for science fiction: "Why are you bothering to teach that stuff?" Science fiction has achieved a place in the academic canon, but its adherents worry about being relegated to a second-class berth.

Evidence for either the canonization or continued marginalization of science fiction might be found in the collecting practices of academic libraries. Indeed, one could argue that the support given science fiction scholars by academic libraries - in the form of collections of primary and secondary works - is an indicator of just how accepted science fiction is by the broader scholarly community. However, a search of the library literature suggests that there have been few studies of the extent to which academic libraries acquire science fiction primary texts-novels, magazines, or short fiction collections. Most mentions of science fiction in library literature are reviews, discussions of recommended reading lists, announcements of major gifts, or descriptions of special collections. Hal W. Hall's collection of essays, Science Fiction Collections: Fantasy, Supernatural and Weird Tales, for example, profiles a few major research collections rather than assessing a large number of collections. ${ }^{3}$ Hall's chapter, "Research Library Collections of Science Fiction," in the new fifth edition of Anatomy of Wonder (which appeared as this essay was being revised for publication) offers additional profiles and statistical data about the best collections of science fiction among academic, public, and national libraries but does not attempt to assess a wider range of collections. ${ }^{4}$ This study complements Hall's work by examining the collecting practices of a specific population of academic libraries. To what extent has science fiction been included in the canon of literature collected by academic libraries? This study attempts to begin to answer that question.
The author decided to focus on academic members of the ARL rather than attempt to study all academic libraries or develop a random sample, so the present study (along with any conclusions drawn from it) is limited to larger academic libraries, a group that includes a high proportion of the most prestigious academic libraries in the United States and Canada. All ARL academic libraries were included, except for two Canadian libraries whose French-language catalog interface posed too great a linguistic challenge, for a total of 112 libraries. ${ }^{5}$ To assess how ARL academic libraries collect science fiction, a core list of 200 science fiction novels was developed and then checked against WorldCat, the RLG (Research Libraries Group) Union Catalog, and individual library catalogs. The science fiction novels selected were published from 1950 to 2000. Before 1950, science fiction, at least in the United States, was published predominantly in the form of short stories and serialized novels in pulp magazines, but the subsequent half-century witnessed a proliferation of novels published in hardcover and paperback editions. ${ }^{6}$ The focus on novels is admittedly a limitation because short stories-published in magazines, author collections, and anthologies-remain a vital part of the output of science fiction. Thus, a future study might usefully complement the present one by finding an appropriate methodology for assessing short fiction holdings.

The core list of novels was developed by collating lists of major science fiction awards. (See table 1.) The list then was supplemented with a number of novels that were not award winners but had attained classic status in the field, as manifested by their presence in lists of the best or most frequently taught novels (by Neil Barron, David Pringle, Arthur Evans, and R. D. Mullen ${ }^{7}$ ) and/or the amount of critical attention they have attracted. Relying on multiple awards and critical reputation provides a more truly representative list of top science fiction novels 


\begin{tabular}{|c|c|c|c|c|}
\hline \multicolumn{5}{|c|}{$\begin{array}{c}\text { TABLE } 1 \\
\text { Science Fiction Awards }\end{array}$} \\
\hline Award & Abb. & Organization & Time Period & $\begin{array}{l}\text { Selection } \\
\text { Method }\end{array}$ \\
\hline $\begin{array}{l}\text { Arthur C. Clarke Award } \\
\text { (novels published in U.K.) }\end{array}$ & A & $\begin{array}{l}\text { Science Fiction } \\
\text { Foundation }\end{array}$ & $1987+$ & Panel of judges \\
\hline $\begin{array}{l}\text { British Science Fiction } \\
\text { Award }\end{array}$ & B & $\begin{array}{l}\text { British Science } \\
\text { Fiction Association }\end{array}$ & $1969+$ & Member vote \\
\hline $\begin{array}{l}\text { John W. Campbell } \\
\text { Memorial Award (novels } \\
\text { published in U.S.) }\end{array}$ & $\mathrm{C}$ & & $1972+$ & Selected judges \\
\hline $\begin{array}{l}\text { Philip K. Dick Award } \\
\text { (best original paperback) }\end{array}$ & $\mathrm{D}$ & $\begin{array}{l}\text { Philadelphia } \\
\text { Science Fiction } \\
\text { Society (sponsors) }\end{array}$ & $1982+$ & Selected judges \\
\hline Hugo Award & $\mathrm{H}$ & $\begin{array}{l}\text { World Science } \\
\text { Fiction Convention }\end{array}$ & $1953+$ & $\begin{array}{l}\text { Fans registered } \\
\text { for convention }\end{array}$ \\
\hline Locus Award & $\mathrm{L}$ & Locus Magazine & $1970+$ & Locus readers \\
\hline Nebula Award & $\mathrm{N}$ & $\begin{array}{l}\text { Science Fiction } \\
\text { and Fantasy } \\
\text { Writers of America }\end{array}$ & $1965+$ & $\begin{array}{l}\text { Professional } \\
\text { science fiction and } \\
\text { fantasy writers }\end{array}$ \\
\hline $\begin{array}{l}\text { James Tiptree Jr. Award } \\
\text { (for "gender-bending" } \\
\text { fiction) }\end{array}$ & $\mathrm{T}$ & $\begin{array}{l}\text { James Tiptree Jr. } \\
\text { Literary Award } \\
\text { Council }\end{array}$ & $\begin{array}{l}1991+\text { (with } \\
\text { "retrospective } \\
\text { awards") }\end{array}$ & Selected judges \\
\hline
\end{tabular}

than selecting winners of a single award or relying on the choices of a single critic. It should be noted that although a couple of award-winning novels that were clearly fantasy (for example, Ursula K. Le Guin's Tehanu) were excluded and the list of award winners was not supplemented with any additional fantasy novels, no rigorous effort was made to limit the study to novels that met any narrow definition of science fiction. In almost all cases, the award was accepted simply as proof of the work's belonging to the genre. Certainly it could be argued that some of the novels on the list, such as Neal Stephenson's Cryptonomicon and Molly Gloss's Wild Life, are not "really" science fiction, but they are nonetheless included as winners of science fiction awards. Although no one list could please all students of science fiction, this selection includes a significant proportion of the most popular, most influential, and most highly regarded science fiction novels of the second half of the twentieth century in the Englishspeaking world.

It should be noted that at least two other approaches would yield valuable insights into how science fiction is collected at academic libraries. One could count (or estimate) the number of science fiction titles owned by each library, as Hall did for a small number of libraries with very strong science fiction collections. ${ }^{8}$ Useful as such information is, a purely statistical approach would not by itself identify the comparative strengths and weaknesses of collections or offer a detailed assessment of their scope or quality. One also could select a few major authors (for example, Heinlein, Le Guin, Clarke, or Dick) and study how those authors are collected: the proportion of their entire published output owned by a library, including multiple editions; holdings of secondary works such as criticism, bibliography, and biography; and holdings of primary materials such 
as manuscripts and correspondence. This approach would yield a highly focused qualitative assessment of the collections, but at the sacrifice of a broader evaluation of collection quality. The approach in this study strives to provide both quantitative and qualitative assessments of the science fiction collections examined, with some attention to both breadth and depth, but it complements rather than precludes those alternate approaches.

Although novels were not deliberately restricted to a particular language or nationality, the selection criteria used in this study (American and British awards and critical attention) in effect limited the books included primarily to titles published in English. Only two were originally published in other languages: Stanislaw Lem's Solaris (Polish) and Robert Merle's Malevil (French). It would be interesting to conduct a similar study of how ARL libraries collect non-Englishlanguage science fiction, whether in the original language or in translation. It is highly likely that the holdings of nonEnglish-language science fiction from the period studied (with the possible exception of the works of Stanislaw Lem) would be dramatically lower than for English-language works.

After the list of novels was developed, a search was performed to find which of the ARL academic libraries owned each book. WorldCat was checked for each title, then the RLG Union Catalog. Spot-checking of some titles suggested the need to supplement the search of the major bibliographic utilities with searches of individual online catalogs. The author ended up examining the individual online catalogs of all 112 libraries (searching only for those titles not previously found in WorldCat or the RLG Union Catalog). Alternate titles of novels and all editions or printings owned by libraries were included. A novel was considered "owned" by a library as long as any printing or edition was listed as owned, on order, or even missing, because the intent was simply to see if science fiction novels were being selected. Searching was carried out between May 2002 and February 2003. Ideally, all catalogs would have been searched at the same time, or within a few weeks, but because the author was the only available searcher, it took much longer. What was developed, then, was a snapshot of holdings during a particular period. It should be stressed that almost certainly libraries have acquired more of these titles (especially some of the more current novels, but older ones as well) since the search was completed. One weakness in this approach is that some libraries have science fiction holdings not included in online catalogs, for example, in recent gift collections or in parts of the collection for which there are as yet no machine-readable records. Thus, holdings might be higher than indicated by the searches conducted as part of this study, although it could be argued that absence from online catalogs would make titles effectively invisible to most users.

The study began with a number of expectations. For example, it was assumed that works of better-known authors would be owned by more libraries than would works of lesser-known authors (even though lesser-known authors such as Gene Wolfe are often more highly regarded by scholars and critics than their more famous peers). Further, it was expected that most libraries would own the works of the most famous science fiction writers (Isaac Asimov, Arthur C. Clarke, Robert A. Heinlein, Ursula K. Le Guin, among others). Moreover, it was thought that most libraries would own novels by writers with substantial reputations for their work in fields outside science fiction, crossover writers such as Margaret Atwood, Kingsley Amis, and Marge Piercy. Conversely, it was expected that fewer libraries would own the novels of writers little known outside the field of science fiction or the novels of newer writers who have had less time to establish their reputations. The author also was curious to see whether the writer's gender or nationality made a difference in how libraries col- 
lect science fiction. It was felt that ARL libraries were more likely to collect the works of American writers than those of non-American writers and the works of male authors rather than those of female writers. Moreover, the author expected that more recent works would be more widely held than earlier titles.

The results revealed a wide variation in library holdings of the science fiction novels studied. The mean number

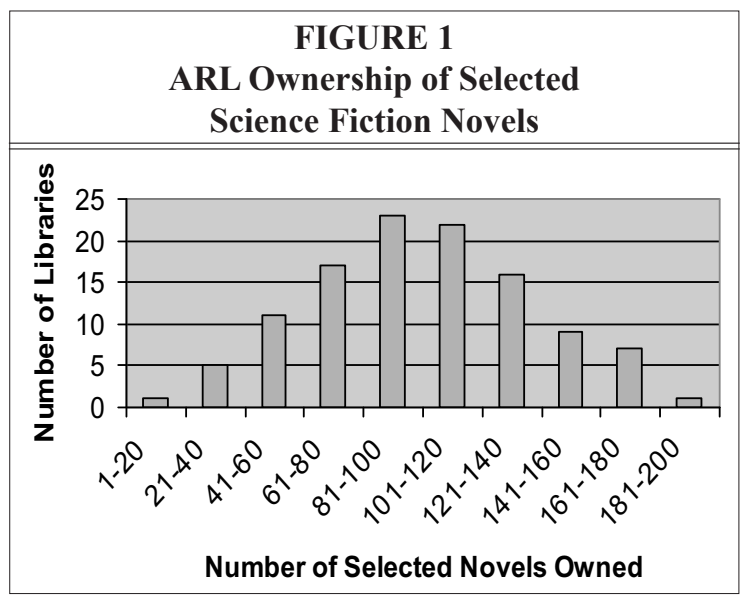
of novels owned by the ARL academic libraries is 100.18 (or $50 \%$ of the novels), and the median is 98 (or $49 \%$ ). On the other hand, the range was quite wide, from 194 novels owned (97\%) to 18 novels owned $(9 \%)$, and the standard deviation was 37.3. As figure 1 indicates, library holdings follow a normal, bell-shaped distribution. To the extent that the list of novels represents the best of science fiction novels, clearly there are great differences in the way ARL libraries collect those works. Some libraries collect comprehensively; most collect extensively, but not comprehensively; and others own few of even the widely acknowledged classics of the field. (See table 2.) The data suggest that although science fiction has made significant inroads in the academy, few ARL libraries are collecting it at anything approaching a comprehensive level. The relatively sparse holdings of the 200 novels studied are striking because those novels comprise a small and highly select subset of the universe of science fiction novels published during the period. The author is not aware of an authoritative count of the number of new science fiction novels published between 1950 and 2000, but there are reliable counts for some years within the period. Using The Locus Index to Science Fiction, Neil Barron has estimated about 300 new science fiction novels per year between 1988 and 1994; Locus tallies 288 for 1999 and 269 for $2000 .{ }^{9}$ If one assumes a drastically lower output

for much of the 1950s and 1960s and a somewhat lower output for the 1970s and early 1980s, it is still quite evident that the 200 novels studied here comprise a small proportion of all the science fiction novels published in the fifty-year period under study. Even if one were to posit a low-end estimate of 100 new science fiction novels published per year during the period (an extremely conservative estimate), the total would be 5,000 novels - and the subset of 200 novels would be only four percent of the total. Thus, the average ARL academic library owns barely half of a highly selective list of the best science fiction novels published in the latter half of the twentieth century.

In one sense, it would be unfair to criticize the libraries that rank low in this study as it is likely that they collect little science fiction because there is little or no demand for it on the part of their faculty and students or because it is not included in their collection scope (or perhaps because funds are lacking for what might be seen as a popular rather than scholarly field). Yet, it is a matter of concern that ARL academic libraries have, for the most part, quite limited collections of a literature increasingly studied. A future study might examine how frequently science fiction is explicitly mentioned in collection policy statements at ARL academic libraries and might explore the correlation between the teaching of science fiction 


\begin{tabular}{|c|c|c|c|}
\hline \multicolumn{4}{|c|}{$\begin{array}{c}\text { TABLE } 2 \\
\text { ARL Academic Libraries Ranked by Holdings of Selected Science Fiction }\end{array}$} \\
\hline Rank & Library & $\begin{array}{c}\text { Number of } \\
\text { Books on List } \\
\text { Owned }\end{array}$ & $\begin{array}{l}\text { Percentage of } \\
\text { List Owned }\end{array}$ \\
\hline 1 & University of California-Riverside & 194 & $97.0 \%$ \\
\hline 2 & University of Texas-Austin & 172 & $86.0 \%$ \\
\hline 3 & Texas A\&M University & 169 & $84.5 \%$ \\
\hline 3 & University of Wisconsin-Madison & 169 & $84.5 \%$ \\
\hline 5 & Emory University & 165 & $82.5 \%$ \\
\hline 6 & Brigham Young University & 163 & $81.5 \%$ \\
\hline 6 & State University of New York-Buffalo & 163 & $81.5 \%$ \\
\hline 8 & University of North Carolina-Chapel Hill & 162 & $81.0 \%$ \\
\hline 9 & Michigan State University & 160 & $80.0 \%$ \\
\hline 9 & Ohio State University & 160 & $80.0 \%$ \\
\hline 11 & University of Colorado & 151 & $75.5 \%$ \\
\hline 12 & University of Virginia & 149 & $74.5 \%$ \\
\hline 13 & Colorado State University & 145 & $72.5 \%$ \\
\hline 14 & University of Georgia & 143 & $71.5 \%$ \\
\hline 15 & Washington State University & 142 & $71.0 \%$ \\
\hline 16 & University of Illinois-Urbana-Champaign & 141 & $70.5 \%$ \\
\hline 16 & Pennsylvania State University & 141 & $70.5 \%$ \\
\hline 18 & University of Alberta & 140 & $70.0 \%$ \\
\hline 18 & Stanford University & 140 & $70.0 \%$ \\
\hline 20 & University of Pennsylvania & 139 & $69.5 \%$ \\
\hline 21 & Princeton University & 138 & $69.0 \%$ \\
\hline 22 & University of Utah & 137 & $68.5 \%$ \\
\hline 23 & Temple University & 136 & $68.0 \%$ \\
\hline 24 & Yale University & 134 & $67.0 \%$ \\
\hline 25 & University of Toronto & 133 & $66.5 \%$ \\
\hline 26 & University of Kansas & 132 & $66.0 \%$ \\
\hline 27 & Duke University & 131 & $65.5 \%$ \\
\hline 28 & University of Iowa & 129 & $64.5 \%$ \\
\hline 29 & Auburn University & 127 & $63.5 \%$ \\
\hline 30 & Louisiana State University & 124 & $62.0 \%$ \\
\hline 31 & University of California-Berkeley & 123 & $61.5 \%$ \\
\hline 32 & Indiana University & 122 & $61.0 \%$ \\
\hline 33 & University of Miami (Florida) & 121 & $60.5 \%$ \\
\hline 34 & University of Arizona & 118 & $59.0 \%$ \\
\hline 35 & University of Michigan & 117 & $58.5 \%$ \\
\hline
\end{tabular}




\begin{tabular}{|c|c|c|c|}
\hline \multicolumn{4}{|c|}{$\begin{array}{c}\text { TABLE } 2 \\
\text { ARL Academic Libraries Ranked by Holdings of Selected Science Fiction }\end{array}$} \\
\hline Rank & Library & $\begin{array}{c}\text { Number of } \\
\text { Books on List } \\
\text { Owned }\end{array}$ & $\begin{array}{l}\text { Percentage of } \\
\text { List Owned }\end{array}$ \\
\hline 36 & University of British Columbia & 116 & $58.0 \%$ \\
\hline 37 & University of California-Los Angeles & 115 & $57.5 \%$ \\
\hline 37 & Harvard University & 115 & $57.5 \%$ \\
\hline 39 & University of South Carolina & 114 & $57.0 \%$ \\
\hline 40 & Georgia Institute of Technology & 113 & $56.5 \%$ \\
\hline 41 & Arizona State University & 112 & $56.0 \%$ \\
\hline 41 & Brown University & 112 & $56.0 \%$ \\
\hline 41 & University of California-San Diego & 112 & $56.0 \%$ \\
\hline 41 & University of Pittsburgh & 112 & $56.0 \%$ \\
\hline 45 & University of Delaware & 111 & $55.5 \%$ \\
\hline 46 & North Carolina State University & 110 & $55.0 \%$ \\
\hline 47 & University of Houston & 109 & $54.5 \%$ \\
\hline 48 & Tulane University & 108 & $54.0 \%$ \\
\hline 49 & Florida State University & 107 & $53.5 \%$ \\
\hline 49 & University of Washington & 107 & $53.5 \%$ \\
\hline 51 & Northwestern University & 105 & $52.5 \%$ \\
\hline 51 & University of Oregon & 105 & $52.5 \%$ \\
\hline 51 & State University of New York-Albany & 105 & $52.5 \%$ \\
\hline 54 & Cornell University & 103 & $51.5 \%$ \\
\hline 54 & Iowa State University & 103 & $51.5 \%$ \\
\hline 56 & Massachusetts Institute of Technology & 99 & $49.5 \%$ \\
\hline 57 & University of California-Davis & 97 & $48.5 \%$ \\
\hline 57 & University of Minnesota & 97 & $48.5 \%$ \\
\hline 57 & Texas Tech University & 97 & $48.5 \%$ \\
\hline 60 & University of Louisville & 94 & $47.0 \%$ \\
\hline 61 & Purdue University & 92 & $46.0 \%$ \\
\hline 61 & University of Tennessee-Knoxville & 92 & $46.0 \%$ \\
\hline 63 & Oklahoma State University & 90 & $45.0 \%$ \\
\hline 64 & University of Florida & 89 & $44.5 \%$ \\
\hline 64 & McMaster University & 89 & $44.5 \%$ \\
\hline 64 & Rice University & 89 & $44.5 \%$ \\
\hline 64 & University of Rochester & 89 & $44.5 \%$ \\
\hline 64 & Syracuse University & 89 & $44.5 \%$ \\
\hline 69 & University of Connecticut & 88 & $44.0 \%$ \\
\hline 70 & Kent State University & 87 & $43.5 \%$ \\
\hline
\end{tabular}




\begin{tabular}{|c|c|c|c|}
\hline \multicolumn{4}{|c|}{$\begin{array}{c}\text { TABLE } 2 \\
\text { ARL Academic Libraries Ranked by Holdings of Selected Science Fiction }\end{array}$} \\
\hline Rank & Library & $\begin{array}{c}\text { Number of } \\
\text { Books on List } \\
\text { Owned }\end{array}$ & $\begin{array}{l}\text { Percentage of } \\
\text { List Owned }\end{array}$ \\
\hline 70 & University of Waterloo & 87 & $43.5 \%$ \\
\hline 72 & Southern Illinois University & 86 & $43.0 \%$ \\
\hline 72 & Washington University-St. Louis & 86 & $43.0 \%$ \\
\hline 74 & Rutgers University & 84 & $42.0 \%$ \\
\hline 75 & University of Southern California & 83 & $41.5 \%$ \\
\hline 76 & McGill University & 81 & $40.5 \%$ \\
\hline 76 & University of New Mexico & 81 & $40.5 \%$ \\
\hline 76 & Virginia Tech & 81 & $40.5 \%$ \\
\hline 79 & University of California-Irvine & 80 & $40.0 \%$ \\
\hline 80 & University of Chicago & 78 & $39.0 \%$ \\
\hline 81 & University of Hawaii & 76 & $38.0 \%$ \\
\hline 82 & University of Oklahoma & 75 & $37.5 \%$ \\
\hline 82 & York University & 75 & $37.5 \%$ \\
\hline 84 & Columbia University & 72 & $36.0 \%$ \\
\hline 85 & University of Cincinnati & 71 & $35.5 \%$ \\
\hline 86 & Ohio University & 70 & $35.0 \%$ \\
\hline 86 & Queens University & 70 & $35.0 \%$ \\
\hline 88 & Boston College & 69 & $34.5 \%$ \\
\hline 88 & University of Missouri-Columbia & 69 & $34.5 \%$ \\
\hline 90 & Boston University & 67 & $33.5 \%$ \\
\hline 91 & University of Western Ontario & 66 & $33.0 \%$ \\
\hline 92 & University of Guelph & 65 & $32.5 \%$ \\
\hline 92 & Johns Hopkins University & 65 & $32.5 \%$ \\
\hline 94 & University of Maryland-College Park & 61 & $30.5 \%$ \\
\hline 94 & University of Massachusetts & 61 & $30.5 \%$ \\
\hline 96 & Dartmouth College & 59 & $29.5 \%$ \\
\hline 97 & Case Western Reserve University & 58 & $29.0 \%$ \\
\hline 98 & University of Illinois-Chicago & 56 & $28.0 \%$ \\
\hline 98 & New York University & 56 & $28.0 \%$ \\
\hline 100 & University of California-Santa Barbara & 55 & $27.5 \%$ \\
\hline 100 & University of Manitoba & 55 & $27.5 \%$ \\
\hline 102 & University of Kentucky & 53 & $26.5 \%$ \\
\hline 103 & State University of New York-Stony Brook & 47 & $23.5 \%$ \\
\hline 103 & Vanderbilt University & 47 & $23.5 \%$ \\
\hline 105 & University of Notre Dame & 45 & $22.5 \%$ \\
\hline
\end{tabular}


TABLE 2

ARL Academic Libraries Ranked by Holdings of Selected Science Fiction

\begin{tabular}{|c|l|c|c|}
\hline \hline Rank & \multicolumn{1}{|c|}{ Library } & $\begin{array}{c}\text { Number of } \\
\text { Books on List } \\
\text { Owned }\end{array}$ & $\begin{array}{c}\text { Percentage of } \\
\text { List Owned }\end{array}$ \\
\hline 105 & Wayne State University & 45 & $22.5 \%$ \\
\hline 107 & Georgetown University & 37 & $18.5 \%$ \\
\hline 108 & University of Alabama & 34 & $17.0 \%$ \\
\hline 108 & University of Saskatchewan & 34 & $17.0 \%$ \\
\hline 110 & George Washington University & 32 & $16.0 \%$ \\
\hline 111 & University of Nebraska-Lincoln & 28 & $14.0 \%$ \\
\hline 112 & Howard University & 18 & $9.0 \%$ \\
\hline
\end{tabular}

courses and the presence of strong science fiction collections at ARL schools.

There are some interesting intersections between this study and Hall's survey of top research collections. Hall listed thirtyeight U.S. and Canadian libraries with major science fiction research collections, twenty-two of which are ARL academic libraries (the other sixteen include the Library of Congress, the Huntington Library, four public libraries, and ten college and university libraries not in ARL). ${ }^{10}$ There is considerable agreement between this study's list and Hall's. For example, UC Riverside leads this study's list and is described by Hall as the largest science fiction collection and Texas A\&M is the third ranked library on both lists. On the other hand, there are some discrepancies. The University of Louisville is the third largest collection (and the second largest ARL) on Hall's list but ranks only sixtieth in this study, and Temple and Syracuse rank in Hall's top twelve ARL libraries while coming in twenty-third and sixty-fourth, respectively, in this study's list. Some of the differences are explicable in the very nature of a "special" collection. For example, Louisville's large holdings are accounted for primarily by its superb collection of a single author, Edgar Rice Burroughs, who falls outside the chronological scope and only partly within the generic scope of this study. Temple's fine collection (described at http://www.library.temple.edu/collec- tions/special_collections/sfc.htm) is based on several large gifts and focuses on pulp magazines, fanzines, and the manuscripts of a dozen or so authors. The collection at Syracuse also has strengths in pulp magazines, and the collections at both Temple and Syracuse are described by Hall as only partly cataloged. Indeed, Hall noted that "although most of the [Temple] collection (90 percent) was cataloged by 1984, the influx of gifts has since reduced the portion of cataloged material to about half." 11 Many of the best science fiction special collections are thus characterized by tremendous depth, rather than breadth, or lag in providing complete records of their holdings. Simply put, the scope and audience of special collections, though in many ways overlapping with general ARL collections, are distinctive. (See table 3.)

To see if there was any correlation between library size or budget and science fiction holdings, the author turned to $A R L$ Statistics, selecting five academic years (1974-1975; 1981-1982; 1987-1988; 19941995, and 1999-2000) and looked at two tables, "Total Volumes Held Rankings" and "Total Materials Expenditures Rankings." ${ }^{12}$ He created a crude average rank simply by averaging the rankings of the five years selected and then checked the correlation with the science fiction holding rankings. The correlation between library size and science fiction rankings was positive, but not terribly strong -0.4281 . 


\begin{tabular}{|c|c|c|c|c|c|c|}
\hline \multicolumn{7}{|c|}{$\begin{array}{c}\text { TABLE } 3 \\
\text { Science Fiction Novels Ranked by ARL Ownership }\end{array}$} \\
\hline Rank & Title & Author & $\begin{array}{l}\text { Pub } \\
\text { Date }\end{array}$ & $\begin{array}{l}\text { \# of } \\
\text { Libs }\end{array}$ & $\begin{array}{l}\text { \% of } \\
\text { Libs }\end{array}$ & $\begin{array}{l}\text { Awards/ } \\
\text { Lists }\end{array}$ \\
\hline 1 & Slaughterhouse Five & Vonnegut, Kurt Jr. & 1969 & 111 & $99.10 \%$ & E, NB \\
\hline \multirow[t]{4}{*}{2} & The Handmaid's Tale & Atwood, Margaret & 1985 & 110 & $98.20 \%$ & A \\
\hline & Fahrenheit 451 & Bradbury, Ray & 1953 & 110 & $98.20 \%$ & E, NB, P \\
\hline & Childhood's End & Clarke, Arthur C. & 1953 & 110 & $98.20 \%$ & $\mathrm{E}, \mathrm{NB}, \mathrm{P}$ \\
\hline & The Left Hand of Darkness & Le Guin, Ursula K. & 1969 & 110 & $98.20 \%$ & $\mathrm{H}, \mathrm{N}, \mathrm{T}$ \\
\hline \multirow[t]{3}{*}{6} & Stranger in a Strange Land & Heinlein, Robert A. & 1961 & 109 & $97.30 \%$ & $\mathrm{H}$ \\
\hline & The Dispossessed & Le Guin, Ursula K. & 1974 & 109 & $97.30 \%$ & $\mathrm{H}, \mathrm{L}, \mathrm{N}$ \\
\hline & A Cancticle for Leibowitz & Miller, Walter M. Jr. & 1959 & 109 & $97.30 \%$ & $\mathrm{H}$ \\
\hline \multirow[t]{3}{*}{9} & The Alteration & Amis, Kingsley & 1976 & 108 & $96.40 \%$ & $\mathrm{C}$ \\
\hline & Dune & Herbert, Frank & 1965 & 108 & $96.40 \%$ & $\mathrm{H}, \mathrm{N}$ \\
\hline & Riddley Walker & Hoban, Russell & 1980 & 108 & $96.40 \%$ & $\mathrm{C}$ \\
\hline \multirow[t]{2}{*}{12} & Foundation's Edge & Asimov, Isaac & 1982 & 104 & $92.90 \%$ & $\mathrm{H}, \mathrm{L}$ \\
\hline & The Einstein Intersection & Delany, Samuel R. & 1967 & 104 & $92.90 \%$ & $\mathrm{~N}$ \\
\hline 14 & Neuromancer & Gibson, William & 1984 & 102 & $91.10 \%$ & $\mathrm{D}, \mathrm{H}, \mathrm{N}$ \\
\hline \multirow[t]{3}{*}{15} & The Moon Is a Harsh Mistress & Heinlein, Robert A. & 1966 & 101 & $90.20 \%$ & $\mathrm{H}$ \\
\hline & Flowers for Algernon & Keyes, Daniel & 1966 & 101 & $90.20 \%$ & $\mathrm{~N}$ \\
\hline & He, She and It & Piercy, Marge & 1991 & 101 & $90.20 \%$ & A \\
\hline 18 & The Gods Themselves & Asimov, Isaac & 1972 & 100 & $89.30 \%$ & $\mathrm{H}, \mathrm{L}, \mathrm{N}$ \\
\hline 19 & The Female Man & Russ, Joanna & 1975 & 98 & $87.50 \%$ & $\mathrm{~T}$ \\
\hline \multirow[t]{5}{*}{20} & Heliconia Winter & Aldiss, Brian & 1985 & 96 & $85.70 \%$ & $\mathrm{~B}$ \\
\hline & The Fountains of Paradise & Clarke, Arthur C. & 1979 & 96 & $85.70 \%$ & $\mathrm{H}, \mathrm{N}$ \\
\hline & Rendezvous with Rama & Clarke, Arthur C. & 1973 & 96 & $85.70 \%$ & $\begin{array}{l}\mathrm{B}, \mathrm{C}, \mathrm{H}, \\
\mathrm{L}, \mathrm{N}\end{array}$ \\
\hline & The Lathe of Heaven & Le Guin, Ursula K. & 1971 & 96 & $85.70 \%$ & $\mathrm{~L}$ \\
\hline & The Telling & Le Guin, Ursula K. & 2000 & 96 & $85.70 \%$ & $\mathrm{~L}$ \\
\hline 25 & The Man in the High Castle & Dick, Philip K. & 1962 & 95 & $84.80 \%$ & $\mathrm{H}$ \\
\hline 26 & $\begin{array}{l}\text { Hitchhiker's Guide to the } \\
\text { Galaxy }\end{array}$ & Adams, Douglas & 1979 & 94 & $83.90 \%$ & $\mathrm{E}$ \\
\hline 27 & Dhalgren & Delany, Samuel R. & 1975 & 93 & $83.00 \%$ & $\mathrm{NB}$ \\
\hline \multirow[t]{2}{*}{28} & Heliconia Spring & Aldiss, Brian & 1982 & 92 & $82.10 \%$ & $\mathrm{~B}, \mathrm{C}$ \\
\hline & The Demolished Man & Bester, Alfred & 1953 & 92 & $82.10 \%$ & $\mathrm{H}$ \\
\hline \multirow[t]{3}{*}{30} & The Stars My Destination & Bester, Alfred & 1956 & 90 & $80.40 \%$ & E, NB, P \\
\hline & Stand On Zanzibar & Brunner, John & 1968 & 90 & $80.40 \%$ & $\mathrm{~B}, \mathrm{H}$ \\
\hline & $\begin{array}{l}\text { Where Late the Sweet Birds } \\
\text { Sang }\end{array}$ & Wilhelm, Kate & 1976 & 90 & $80.40 \%$ & $\mathrm{H}, \mathrm{L}$ \\
\hline 33 & The Crystal World & Ballard, J. G. & 1966 & 89 & $79.50 \%$ & $\mathrm{NB}, \mathrm{P}$ \\
\hline 34 & $\begin{array}{l}\text { The Unlimited Dream } \\
\text { Company }\end{array}$ & Ballard, J. G. & 1979 & 88 & $78.60 \%$ & B \\
\hline
\end{tabular}


Science Fiction Collections in ARL Academic Libraries 25

\begin{tabular}{|c|c|c|c|c|c|c|}
\hline & Science Fiction & $\begin{array}{c}\text { TABLE } 3 \\
\text { Iovels Ranked by }\end{array}$ & L Ow & nerst & & \\
\hline Rank & Title & Author & $\begin{array}{l}\text { Pub } \\
\text { Date }\end{array}$ & $\begin{array}{l}\text { \# of } \\
\text { Libs }\end{array}$ & $\begin{array}{l}\text { \% of } \\
\text { Libs }\end{array}$ & $\begin{array}{c}\text { Awards/ } \\
\text { Lists }\end{array}$ \\
\hline & Gateway & Pohl, Frederik & 1977 & 88 & $78.60 \%$ & $\begin{array}{l}\mathrm{C}, \mathrm{H} \\
\mathrm{L}, \mathrm{N}\end{array}$ \\
\hline & More Than Human & Sturgeon, Theodore & 1953 & 88 & $78.60 \%$ & E, NB, P \\
\hline 37 & Lord of Light & Zelazny, Roger & 1967 & 86 & $76.80 \%$ & $\mathrm{H}$ \\
\hline & Ender's Game & Card, Orson Scott & 1985 & 86 & $76.80 \%$ & $\mathrm{H}, \mathrm{N}$ \\
\hline & The Space Merchants & $\begin{array}{l}\text { Pohl \& Kornblunth, } \\
\text { Cyril }\end{array}$ & 1953 & 86 & $76.80 \%$ & E, NB, P \\
\hline 40 & Cryptonomicon & Stephenson, Neal & 1999 & 85 & $75.80 \%$ & $\mathrm{~L}$ \\
\hline 41 & Dreamsnake & McIntyre, Vonda N. & 1978 & 84 & $75.00 \%$ & $\mathrm{H}, \mathrm{L}, \mathrm{N}$ \\
\hline 42 & Dragonflight & McCaffrey, Anne & 1968 & 83 & $74.10 \%$ & $\mathrm{H}^{*}, \mathrm{~N}^{*}$ \\
\hline & Man Plus & Pohl, Frederik & 1976 & 83 & $74.10 \%$ & $\mathrm{~N}$ \\
\hline 44 & The Big Time & Leiber, Fritz & 1958 & 82 & $73.20 \%$ & $\mathrm{H}$ \\
\hline & Solaris & Lem, Stanislaw & 1961 & 82 & $73.20 \%$ & $\mathrm{E}, \mathrm{NB}$ \\
\hline 46 & Babel 17 & Delany, Samuel R. & 1966 & 81 & $72.30 \%$ & $\mathrm{~N}$ \\
\hline & The Calcutta Chromosome & Ghosh, Amitav & 1995 & 81 & $72.30 \%$ & A \\
\hline & Malevil & Merle, Robert & 1972 & 81 & $72.30 \%$ & $\mathrm{C}$ \\
\hline 49 & Double Star & Heinlein, Robert A. & 1956 & 80 & $71.40 \%$ & $\mathrm{H}$ \\
\hline & $\begin{array}{l}\text { Memoirs of Elizabeth } \\
\text { Frankenstein }\end{array}$ & Roszak, Theodore & 1995 & 80 & $71.40 \%$ & $\mathrm{~T}$ \\
\hline 51 & Timescape & Benford, Gregory & 1980 & 79 & $70.50 \%$ & $\mathrm{~B}, \mathrm{C}, \mathrm{N}$ \\
\hline & Ringworld & Niven, Larry & 1970 & 79 & $70.50 \%$ & $\mathrm{H}, \mathrm{L}, \mathrm{N}$ \\
\hline & Snow Queen & Vinge, Joan & 1980 & 79 & $70.50 \%$ & $\mathrm{H}, \mathrm{L}$ \\
\hline 54 & A Case of Conscience & Blish, James & 1959 & 78 & $69.60 \%$ & $\mathrm{H}$ \\
\hline 55 & The Midwich Cuckoos & Wyndham, John & 1957 & 77 & $68.80 \%$ & $\mathrm{NB}, \mathrm{P}$ \\
\hline 56 & The Postman & Brin, David & 1985 & 75 & $67.00 \%$ & $\mathrm{C}, \mathrm{L}$ \\
\hline & The Parable of the Talents & Butler, Octavia E. & 1998 & 75 & $67.00 \%$ & $\mathrm{~N}$ \\
\hline & Dying Inside & Silverberg, Robert & 1972 & 75 & $67.00 \%$ & NB \\
\hline 59 & The Difference Engine & Gibson \& Sterling & 1990 & 74 & $66.10 \%$ & \\
\hline 60 & Speaker for the Dead & Card, Orson Scott & 1985 & 73 & $65.20 \%$ & $\mathrm{H}, \mathrm{N}$ \\
\hline & On Wings of Song & Disch, Thomas M. & 1979 & 73 & $65.20 \%$ & $\mathrm{C}$ \\
\hline & To Your Scattered Bodies Go & Farmer, Philip Jose & 1971 & 73 & $65.20 \%$ & $\mathrm{H}$ \\
\hline & The Forever War & Haldeman, Joe & 1974 & 73 & $65.20 \%$ & $\mathrm{H}, \mathrm{L}, \mathrm{N}$ \\
\hline & The Wanderer & Leiber, Fritz & 1964 & 73 & $65.20 \%$ & $\mathrm{H}$ \\
\hline & Way Station & Simak, Clifford & 1963 & 73 & $65.20 \%$ & $\mathrm{H}$ \\
\hline & This Immortal & Zelazny, Roger & 1965 & 73 & $65.20 \%$ & $\mathrm{H}$ \\
\hline 67 & Starship Troopers & Heinlein, Robert A. & 1959 & 72 & $64.30 \%$ & $\mathrm{H}$ \\
\hline 68 & Time of Changes & Silverberg, Robert & 1971 & 71 & $63.40 \%$ & $\mathrm{~N}$ \\
\hline & Claw of the Conciliator & Wolfe, Gene & 1981 & 71 & $63.40 \%$ & $\mathrm{~N}$ \\
\hline
\end{tabular}




\begin{tabular}{|c|c|c|c|c|c|c|}
\hline & Science Fiction & $\begin{array}{c}\text { TABLE } 3 \\
\text { ovels Ranked by Al }\end{array}$ & $\mathrm{LO} \mathbf{O r}$ & nersl & & \\
\hline Rank & Title & $\begin{array}{ll}\text { Author } \\
\end{array}$ & $\begin{array}{l}\text { Pub } \\
\text { Date }\end{array}$ & $\begin{array}{l}\text { \# of } \\
\text { Libs }\end{array}$ & $\begin{array}{l}\text { \% of } \\
\text { Libs }\end{array}$ & $\begin{array}{c}\text { Awards/ } \\
\text { Lists }\end{array}$ \\
\hline 70 & Rite of Passage & Panshin, Alexei & 1968 & 70 & $62.50 \%$ & $\mathrm{~N}$ \\
\hline & Red Mars & Robinson, Kim Stanley & 1992 & 70 & $62.50 \%$ & $\mathrm{~B}, \mathrm{~N}$ \\
\hline 72 & The Sparrow & Russell, Mary Doria & 1996 & 69 & $61.60 \%$ & $\mathrm{~A}, \mathrm{~B}, \mathrm{~T}$ \\
\hline 73 & Barefoot in the Head & Aldiss, Brian & 1969 & 68 & $60.70 \%$ & NB \\
\hline & Mission of Gravity & Clement, Hal & 1954 & 68 & $60.70 \%$ & E, NB, P \\
\hline 75 & A Scanner Darkly & Dick, Philip K. & 1977 & 67 & $59.80 \%$ & B \\
\hline & Past Master & Lafferty, R. A. & 1968 & 67 & $59.80 \%$ & NB \\
\hline & Citadel of the Autarch & Wolfe, Gene & 1983 & 67 & $59.80 \%$ & $\mathrm{C}$ \\
\hline 78 & The Integral Trees & Niven, Larry & 1984 & 66 & $58.90 \%$ & $\mathrm{~L}$ \\
\hline & Diamond Age & Stephenson, Neal & 1995 & 66 & $58.90 \%$ & $\mathrm{H}, \mathrm{L}$ \\
\hline & The Shadow of the Torturer & Wolfe, Gene & 1980 & 66 & $58.90 \%$ & $\mathrm{~B}$ \\
\hline 81 & Rogue Moon & Budrys, Algis & 1960 & 65 & $58.00 \%$ & $\mathrm{NB}, \mathrm{P}$ \\
\hline & The Lovers & Farmer, Philip Jose & 1961 & 65 & $58.00 \%$ & NB \\
\hline & Titan & Varley, John & 1979 & 65 & $58.00 \%$ & $\mathrm{~L}$ \\
\hline 84 & Startide Rising & Brin, David & 1983 & 63 & $56.30 \%$ & $\mathrm{H}, \mathrm{L}, \mathrm{N}$ \\
\hline 85 & Blood Music & Bear, Greg & 1985 & 62 & $55.40 \%$ & $\mathrm{H}^{*}, \mathrm{~N}^{*}$ \\
\hline & Wild Life & Gloss, Molly & 2000 & 62 & $55.40 \%$ & $\mathrm{~T}$ \\
\hline & A Mirror for Observers & Pangborn, Edgar & 1954 & 62 & $55.40 \%$ & $\mathrm{NB}, \mathrm{P}$ \\
\hline & Pavane & Roberts, Keith & 1968 & 62 & $55.40 \%$ & $\mathrm{NB}, \mathrm{P}$ \\
\hline & The Drowning Towers & Turner, George & 1987 & 62 & $55.40 \%$ & $\mathrm{~A}$ \\
\hline 90 & Camp Concentration & Disch, Thomas M. & 1968 & 61 & $54.50 \%$ & $\mathrm{NB}, \mathrm{P}$ \\
\hline & Years of the City & Pohl, Frederik & 1984 & 61 & $54.50 \%$ & $\mathrm{C}$ \\
\hline & Door into Ocean & Slonczewski, Joan & 1986 & 61 & $54.50 \%$ & $\mathrm{C}$ \\
\hline 93 & $\begin{array}{l}\text { Flow My Tears, The } \\
\text { Policeman Said }\end{array}$ & Dick, Philip K. & 1974 & 60 & $53.60 \%$ & $\mathrm{C}$ \\
\hline & Blue Mars & Robinson, Kim Stanley & 1996 & 60 & $53.60 \%$ & $\mathrm{H}, \mathrm{L}$ \\
\hline & Green Mars & Robinson, Kim Stanley & 1994 & 60 & $53.60 \%$ & $\mathrm{H}, \mathrm{L}$ \\
\hline 96 & The Body Snatchers & Finney, Jack & 1955 & 58 & $51.80 \%$ & NB \\
\hline & Behold the Man & Moorcock, Michael & 1969 & 58 & $51.80 \%$ & $\mathrm{~N}^{*}$ \\
\hline 98 & The Jagged Orbit & Brunner, John & 1969 & 57 & $50.90 \%$ & $\mathrm{~B}$ \\
\hline 99 & The Inverted World & Priest, Christopher & 1974 & 56 & $50.00 \%$ & $\mathrm{~B}$ \\
\hline & Doomsday Book & Willis, Connie & 1992 & 56 & $50.00 \%$ & $\mathrm{H}, \mathrm{L}, \mathrm{N}$ \\
\hline & To Say Nothing of the Dog & Willis, Connie & 1997 & 56 & $50.00 \%$ & $\mathrm{H}, \mathrm{L}$ \\
\hline 102 & Downbelow Station & Cherryh, C. J. & 1981 & 55 & $49.10 \%$ & $\mathrm{H}$ \\
\hline & Grass & Tepper, Sheri S. & 1989 & 55 & $49.00 \%$ & NB \\
\hline 104 & Hyperion & Simmons, Dan & 1989 & 54 & $48.20 \%$ & $\mathrm{H}, \mathrm{L}$ \\
\hline & Bug Jack Barron & Spinrad, Norman & 1969 & 54 & $48.20 \%$ & $\mathrm{NB}, \mathrm{P}$ \\
\hline & Limbo & Wolfe, Bernard & 1952 & 54 & $48.20 \%$ & $\mathrm{NB}, \mathrm{P}$ \\
\hline
\end{tabular}


Science Fiction Collections in ARL Academic Libraries 27

\begin{tabular}{|c|c|c|c|c|c|c|}
\hline & Science Fiction & $\begin{array}{c}\text { TABLE } 3 \\
\text { ovels Ranked by AI }\end{array}$ & L Ow & nerst & & \\
\hline Rank & Title & Author & \begin{tabular}{l|} 
Pub \\
Date
\end{tabular} & $\begin{array}{l}\text { \# of } \\
\text { Libs }\end{array}$ & $\begin{array}{l}\text { \% of } \\
\text { Libs }\end{array}$ & $\begin{array}{l}\text { Awards/ } \\
\text { Lists }\end{array}$ \\
\hline 107 & Mythago Wood & Holdstock, Robert & 1984 & 53 & $47.30 \%$ & $\mathrm{~B}$ \\
\hline & Norstrilia & Smith, Cordwainer & 1975 & 53 & $47.30 \%$ & $\mathrm{P}$ \\
\hline 109 & Moving Mars & Bear, Greg & 1993 & 52 & $46.40 \%$ & $\mathrm{~N}$ \\
\hline & Walk to the End of the World & Charnas, Suzy Mckee & 1974 & 52 & $46.40 \%$ & $\mathrm{~T}$ \\
\hline 111 & The Many-Colored Land & May, Julian & 1981 & 51 & $45.50 \%$ & $\mathrm{~L}$ \\
\hline 112 & Tau Zero & Anderson, Poul & 1970 & 50 & $44.60 \%$ & NB \\
\hline & No Enemy But Time & Bishop, Michael & 1982 & 50 & $44.60 \%$ & $\mathrm{~N}$ \\
\hline 114 & Make Room! Make Room! & Harrison, Harry & 1966 & 49 & $43.80 \%$ & $\mathrm{NB}, \mathrm{P}$ \\
\hline & The Fall of Hyperion & Simmons, Dan & 1990 & 49 & $43.80 \%$ & $\mathrm{~B}, \mathrm{~L}$ \\
\hline 116 & $\begin{array}{l}\text { Gloriana, or the Unfulfilled } \\
\text { Queen }\end{array}$ & Moorcock, Michael & 1978 & 48 & $42.90 \%$ & $\mathrm{C}$ \\
\hline 117 & Vurt & Noon, Jeff & 1993 & 47 & $42.00 \%$ & A \\
\hline & The Year of the Quiet Sun & Tucker, Wilson & 1970 & 47 & $42.00 \%$ & $\mathrm{C}$ \\
\hline 119 & Cyteen & Cherryh, C. J. & 1989 & 46 & $41.10 \%$ & $\mathrm{H}, \mathrm{L}$ \\
\hline & Beyond Apollo & Malzberg, Barry M. & 1972 & 46 & $41.10 \%$ & $\mathrm{C}$ \\
\hline & Bring the Jubilee & Moore, Ward & 1953 & 46 & $41.10 \%$ & $\mathrm{NB}, \mathrm{P}$ \\
\hline 122 & Perdido Street Station & Mieville, China & 2000 & 45 & $40.20 \%$ & A \\
\hline & Islands in the Net & Sterling, Bruce & 1988 & 45 & $40.20 \%$ & $\mathrm{C}$ \\
\hline & A Fire Upon the Deep & Vinge, Vernor & 1992 & 45 & $40.20 \%$ & $\mathrm{H}$ \\
\hline 125 & Darwin's Radio & Bear, Greg & 1999 & 44 & $39.30 \%$ & $\mathrm{~N}$ \\
\hline & Synthajoy & Compton, D. G. & 1968 & 44 & $39.30 \%$ & \\
\hline & The Extremes & Priest, Christopher & 1998 & 44 & $39.30 \%$ & $\mathrm{~B}$ \\
\hline 128 & Dark Universe & Galouye, Daniel & 1961 & 43 & $38.40 \%$ & NB \\
\hline & Slow River & Griffith, Nicola & 1995 & 43 & $38.40 \%$ & $\mathrm{~N}$ \\
\hline & 253: The Print Remix & Ryman, Geoff & 1998 & 43 & $38.40 \%$ & $\mathrm{D}$ \\
\hline 131 & Lincoln's Dreams & Willis, Connie & 1987 & 42 & $37.50 \%$ & $\mathrm{C}$ \\
\hline 132 & Excession & Banks, Iain M. & 1996 & 41 & $36.60 \%$ & $\mathrm{~B}$ \\
\hline & The Uplift War & Brin, David & 1987 & 41 & $36.60 \%$ & $\mathrm{H}, \mathrm{L}$ \\
\hline 134 & The Forever Peace & Haldeman, Joe & 1997 & 40 & $35.70 \%$ & $\mathrm{C}, \mathrm{H}, \mathrm{N}$ \\
\hline & China Mountain Zhang & McHugh, Maureen & 1992 & 40 & $35.70 \%$ & $\mathrm{~T}$ \\
\hline & Pacific Edge & Robinson, Kim Stanley & 1990 & 40 & $35.70 \%$ & $\mathrm{C}$ \\
\hline 137 & Brown Girl in the Ring & Hopkinson, Nalo & 1998 & 39 & $34.80 \%$ & $\mathrm{~L}$ \\
\hline 138 & Ammonite & Griffith, Nicola & 1993 & 38 & $33.90 \%$ & $\mathrm{~T}$ \\
\hline 139 & Mirror Dance & Bujold, Lois McMaster & 1994 & 37 & $33.00 \%$ & $\mathrm{H}, \mathrm{L}$ \\
\hline & Beggars in Spain & Kress, Nancy & 1993 & 37 & $33.00 \%$ & $\mathrm{H}^{*}, \mathrm{~N}^{*}$ \\
\hline & Kirinyaga & Resnick, Michael D. & 1999 & 37 & $33.00 \%$ & $\mathrm{H}^{*}$ \\
\hline 142 & A Deepness in the Sky & Vinge, Vernor & 1999 & 36 & $32.10 \%$ & $\mathrm{C}, \mathrm{H}$ \\
\hline 143 & The Falling Woman & Murphy, Pat & 1987 & 35 & $31.30 \%$ & $\mathrm{~N}$ \\
\hline
\end{tabular}




\begin{tabular}{|c|c|c|c|c|c|c|}
\hline & Science Fiction I & $\begin{array}{c}\text { TABLE } 3 \\
\text { ovels Ranked by A }\end{array}$ & $\mathbf{L} \mathbf{O W}$ & nerst & & \\
\hline Rank & Title & Author & $\begin{array}{l}\text { Pub } \\
\text { Date }\end{array}$ & $\begin{array}{l}\text { \# of } \\
\text { Libs }\end{array}$ & $\begin{array}{l}\text { \% of } \\
\text { Libs }\end{array}$ & $\begin{array}{l}\text { Awards/ } \\
\text { Lists }\end{array}$ \\
\hline 144 & They'd Rather Be Right & Clifton \& Riley & 1957 & 34 & $30.40 \%$ & $\mathrm{H}$ \\
\hline & Distraction & Sterling, Bruce` & 1998 & 34 & $30.40 \%$ & A \\
\hline 146 & The Vor Game & Bujold, Lois McMaster & 1990 & 33 & $29.50 \%$ & $\mathrm{H}$ \\
\hline & The Jonah Kit & Watson, Ian & 1975 & 33 & $29.50 \%$ & B \\
\hline & Aristoi & Williams, Walter Jon & 1992 & 33 & $29.50 \%$ & \\
\hline 149 & Feersun Endjin & Banks, Iain M. & 1994 & 32 & $28.60 \%$ & B \\
\hline & The White Queen & Jones, Gwyneth & 1991 & 32 & $28.60 \%$ & $\mathrm{~T}$ \\
\hline & The Healer's War & Scarborough, Elizabeth & 1988 & 32 & $28.60 \%$ & $\mathrm{~N}$ \\
\hline 152 & The Child Garden & Ryman, Geoff & 1989 & 31 & $27.70 \%$ & $\mathrm{~A}, \mathrm{C}$ \\
\hline & The Rise of Endymion & Simmons, Dan & 1997 & 31 & $27.70 \%$ & $\mathrm{~L}$ \\
\hline 154 & Orbitsville & Shaw, Bob & 1975 & 30 & $26.80 \%$ & $\mathrm{~B}$ \\
\hline & Synners & Cadigan, Pat & 1991 & 30 & $26.80 \%$ & A \\
\hline 156 & When Gravity Fails & Effinger, George Alec & 1987 & 29 & $25.90 \%$ & NB \\
\hline 157 & The Anubis Gates & Powers, Tim & 1983 & 28 & $25.00 \%$ & $\mathrm{D}$ \\
\hline & Stations of the Tide & Swanwick, Michael & 1991 & 28 & $25.00 \%$ & $\mathrm{~N}$ \\
\hline & Mysterium & Wilson, Robert Charles & 1994 & 28 & $25.00 \%$ & $\mathrm{D}$ \\
\hline & Elvissey & Womack, Jack & 1993 & 28 & $25.00 \%$ & $\mathrm{D}$ \\
\hline 161 & Permutation City & Egan, Greg & 1994 & 27 & $24.10 \%$ & $\mathrm{C}$ \\
\hline & Dinner at Deviant's Palace & Powers, Tim & 1985 & 27 & $24.10 \%$ & $\mathrm{D}$ \\
\hline 163 & Black Wine & Dorsey, Candas Jane & 1997 & 25 & $22.30 \%$ & $\mathrm{~T}$ \\
\hline & Lavondyss & Holdstock, Robert & 1988 & 25 & $22.30 \%$ & B \\
\hline 165 & A Woman of the Iron People & Arnason, Eleanor & 1991 & 24 & $21.40 \%$ & $\mathrm{~T}$ \\
\hline & Barrayar & Bujold, Lois McMaster & 1991 & 24 & $21.40 \%$ & $\mathrm{H}, \mathrm{L}$ \\
\hline & Larque on the Wing & Springer, Nancy & 1994 & 24 & $21.40 \%$ & $\mathrm{~T}$ \\
\hline 168 & Buddy Holly Is Alive and Well & Denton, Bradley & 1991 & 23 & $20.50 \%$ & $\mathrm{C}$ \\
\hline & The Moon and the Sun & McIntyre, Vonda N & 1997 & 23 & $20.50 \%$ & $\mathrm{~N}$ \\
\hline 170 & Falling Free & Bujold, Lois McMaster & 1988 & 21 & $18.80 \%$ & $\mathrm{~N}$ \\
\hline & The Sky Road & MacLeod, Ken & 1999 & 21 & $18.80 \%$ & $\mathrm{~B}$ \\
\hline 172 & The Conqueror's Child & Charnas, Suzy Mckee & 1999 & 20 & $17.90 \%$ & $\mathrm{~T}$ \\
\hline & Pyramids & Pratchett, Terry & 1989 & 20 & $17.90 \%$ & $\mathrm{~B}$ \\
\hline & Tik-Tok & Sladek, John T. & 1983 & 20 & $17.90 \%$ & $\mathrm{~B}$ \\
\hline 175 & Corrupting Dr. Nice & Kessel, John & 1997 & 19 & $17.00 \%$ & \\
\hline & Software & Rucker, Rudy & 1982 & 19 & $17.00 \%$ & $\mathrm{D}$ \\
\hline & Terminal Experiment & Sawyer, Robert & 1995 & 19 & $17.00 \%$ & $\mathrm{~N}$ \\
\hline & Brute Orbits & Zebrowski, George & 1998 & 19 & $17.00 \%$ & $\mathrm{C}$ \\
\hline 179 & The Ragged Astronauts & Shaw, Bob & 1986 & 18 & $16.10 \%$ & $\mathrm{~B}$ \\
\hline 180 & The Time Ships & Baxter, Stephen & 1995 & 14 & $12.50 \%$ & $\mathrm{~B}, \mathrm{C}, \mathrm{D}$ \\
\hline & Fairyland & McAuley, Paul & 1995 & 14 & $12.50 \%$ & $\mathrm{~A}, \mathrm{C}$ \\
\hline
\end{tabular}




\begin{tabular}{|c|c|c|c|c|c|c|}
\hline & Science Fiction & $\begin{array}{c}\text { TABLE } 3 \\
\text { ovels Ranked by }\end{array}$ & L Ov & nersl & & \\
\hline Rank & Title & Author & $\begin{array}{l}\text { Pub } \\
\text { Date }\end{array}$ & $\begin{array}{l}\text { \# of } \\
\text { Libs }\end{array}$ & $\begin{array}{l}\text { \% of } \\
\text { Libs }\end{array}$ & $\begin{array}{c}\text { Awards/ } \\
\text { Lists }\end{array}$ \\
\hline 182 & Homunculus & Blaylock, James & 1986 & 13 & $11.60 \%$ & $\mathrm{D}$ \\
\hline & Growing up Weightless & Ford, John M & 1993 & 13 & $11.60 \%$ & $\mathrm{D}$ \\
\hline & 400 Billion Stars & McAuley, Paul & 1988 & 13 & $11.60 \%$ & $\mathrm{D}$ \\
\hline 185 & Take Back Plenty & Greenland, Colin & 1990 & 12 & $10.70 \%$ & A, B \\
\hline 186 & $\begin{array}{l}\text { King of Morning, Queen of } \\
\text { Day }\end{array}$ & McDonald, Ian & 1991 & 11 & $9.80 \%$ & $\mathrm{D}$ \\
\hline & Wetware & Rucker, Rudy & 1988 & 11 & $9.80 \%$ & $\mathrm{D}$ \\
\hline 188 & Fools & Cadigan, Pat & 1992 & 10 & $8.90 \%$ & A \\
\hline & Subterranean Gallery & Russo, Richard Paul & 1989 & 10 & $8.90 \%$ & $\mathrm{D}$ \\
\hline 190 & Strange Toys & Geary, Patricia & 1987 & 9 & $8.00 \%$ & $\mathrm{D}$ \\
\hline & Dreaming in Smoke & Sullivan, Tricia & 1998 & 9 & $8.00 \%$ & A \\
\hline 192 & Through the Heart & Grant, Richard & 1992 & 8 & $7.10 \%$ & $\mathrm{D}$ \\
\hline & Brother to Dragons & Sheffield, Charles & 1992 & 8 & $7.10 \%$ & $\mathrm{C}$ \\
\hline 194 & Headcrash & Bethke, Bruce & 1995 & 7 & $6.30 \%$ & $\mathrm{D}$ \\
\hline & Brontomek & Coney, Michael D. & 1976 & 7 & $6.30 \%$ & B \\
\hline & Secret History & Gentle, Mary & 2000 & 7 & $6.30 \%$ & B \\
\hline 197 & Aztec Century & Evans, Christopher & 1993 & 5 & $4.50 \%$ & B \\
\hline & Only Forward & $\begin{array}{l}\text { Smith, Michael } \\
\text { Marshall }\end{array}$ & 2000 & 5 & $4.50 \%$ & $\mathrm{D}$ \\
\hline 199 & Grainne & Roberts, Keith & 1987 & 4 & $3.60 \%$ & B \\
\hline 200 & Troika & Chapman, Stephan & 1997 & 2 & $1.80 \%$ & $\mathrm{D}$ \\
\hline $\begin{array}{l}A=A \\
B=B \\
C=J C \\
D=P \\
E=A \\
\text { Litera } \\
H=H \\
L=L \\
N=N \\
N B= \\
P=D \\
T=J a\end{array}$ & $\begin{array}{l}\text { thur C. Clarke Award } \\
\text { itish Science Fiction Award } \\
\text { hn W. Campbell Memorial Ay } \\
\text { ilip K. Dick Award } \\
\text { thur B. Evans and R. D. Mull } \\
\text { ure and Fantasy-The Books } \\
\text { go Award for Best Novel; H* } \\
\text { cus Award } \\
\text { bula Award for Best Novel; } \\
\text { Neil Barron, "Best Books," in } \\
\text { vid Pringle, Science Fiction: } \\
\text { nes Tiptree Jr. Award }\end{array}$ & $\begin{array}{l}\text { "North American Colle } \\
\text { st Widely Assigned" } \\
\text { xpanded version of H } \\
\text { expanded version of } \\
\text { tomy of Wonder } \\
\text { Hundred Best Novels }\end{array}$ & $\begin{array}{l}\text { ourses } \\
\text { vinnin } \\
\text { la-win }\end{array}$ & $\begin{array}{l}\text { in Scie } \\
\text { story/ } \\
\text { ing stc }\end{array}$ & ovella & Utopian \\
\hline Note & author has cited inclusic & he Barron, Evans, a & & & & \\
\hline
\end{tabular}

The correlation between materials budget and science fiction holdings was even weaker-0.3272. In fact, the library with the strongest science fiction holdings consistently scored at the low end of the ARL rankings. This suggests that for many of the most highly ranked ARL libraries sci- ence fiction is not a priority purchase and perhaps that some of the lower-ranked libraries are seeking nontraditional subject areas in which they can excel.

The study also allows some conclusions about novels more likely to be acquired by ARL libraries. Looking at the 


\begin{tabular}{|l|c|c|c|c|c|c|}
\hline \multicolumn{7}{|c|}{ TABLE 4 } \\
Novels by Decade \\
\hline \hline \multicolumn{1}{|c|}{ Decade } & $\mathbf{1 9 5 0 - 5 9}$ & $\mathbf{1 9 6 0 - 6 9}$ & $\mathbf{1 9 7 0 - 7 9}$ & $\mathbf{1 9 8 0 - 8 9}$ & $\mathbf{1 9 9 0 - 9 9}$ & $\mathbf{2 0 0 0}$ \\
\hline Number of novels & 18 & 30 & 34 & 48 & 65 & 5 \\
\hline \% of novels in study & $9 \%$ & $15 \%$ & $17 \%$ & $24 \%$ & $32.5 \%$ & $2.5 \%$ \\
\hline Number in top quartile & 9 & 14 & 15 & 7 & 4 & 1 \\
\hline$\%$ in top quartile & $50 \%$ & $46.7 \%$ & $44 \%$ & $14.6 \%$ & $6.2 \%$ & $20 \%$ \\
\hline Number in top 100 & 15 & 26 & 25 & 20 & 12 & 2 \\
\hline$\%$ in top 100 & $83.3 \%$ & $86.7 \%$ & $73.5 \%$ & $41.7 \%$ & $18.5 \%$ & $40 \%$ \\
\hline
\end{tabular}

top twenty-five novels in table 3 reveals no real surprises in a group dominated by major writers and classic novels. Seventeen of the novels in the top twenty-five also appear on the Evans and Mullen list of most frequently taught novels and twenty-one in Barron's list of best books. ${ }^{13}$ Three writers make multiple appearances in the top twenty-five-Ursula K. Le Guin four times, Arthur C. Clarke three times, and Robert A. Heinlein twice. Indeed, the pattern of writers with more than one novel on the list is common: the 200 novels on the list (including three collaborations) were written by 139 authors. It also is noteworthy that at least four of the writers in the top twenty-five are arguably not science fiction writers in the commonly accepted sense. The works of Amis, Atwood, Piercy, and Vonnegut are rarely marketed as science fiction, and certainly Vonnegut and Atwood take some pains to distance themselves from the genre of science fiction. ${ }^{14}$ Thus, the most popular novels for academic libraries are those by a few leading science fiction writers - the "brand names" - and those by mainstream writers who might, on occasion, write works that can be claimed as science fiction.

Because the novels comprising the list span a half-century of publishing, it would be interesting to see the extent to which library collections were skewed to newer or older titles. Although it was expected that earlier works were less likely to be owned (or at least less likely to be represented in online catalogs and the major bibliographic utilities), in fact, they were more likely to be owned by the greatest number of libraries. (See table 4.) Of the twenty-five novels owned by the most libraries, eleven, or 44 percent, were published in the 1950s and 1960s, even though the novels published during those decades represent only 24 percent of the novels in the study. In contrast, only two, or eight percent, of the top twenty-five were published between 1990 and 2000, even though the novels published in that period comprise 35 percent of the novels in the study. Those two were novels by Ursula K. Le Guin, probably the most critically acclaimed and academically respected science fiction writer of the latter half of the twentieth century, and Marge Piercy, a poet and novelist better known for her non-science fiction work - two writers whose work is likely to be acquired almost automatically by research libraries. As table 4 shows, the same trend is evident in looking at the first quartile or even the top 50 percent. The concern about older works not appearing in online catalogs appears to have been unfounded, and the older novels proved to be more frequently collected than more recent titles.

In retrospect, the selection of novels for this study was perhaps skewed too heavily to the most recent decade, 1990-2000, thus including more novels less fully established as part of the science fiction canon. Of the sixty-five novels included from the decade, sixty did win at least one of the best novel awards and two others were expanded versions of award-winning novellas or 
short stories. But the number of awards has grown over the past two decades, thus inflating the number of novels that can be designated as "award winners." Although the distribution of novels among the first three decades of this study does reflect, at least in rough fashion, science fiction publishing data for that period, the number of novels from the 1980s and the number from 1990s should have been more equal to reflect publishing trends accurately. Nonetheless, what the data suggest is that either ARL libraries have been buying fewer science fiction novels since 1990 or tend to acquire science fiction in a rather slow fashion. With the exception of the works of a few "brandname" authors such as Le Guin (and now perhaps Samuel R. Delany and William Gibson), it is likely that science fiction is currently purchased on a delayed basis by many libraries, acquired only as authors develop reputations, attract increased critical attention, and find their way into college syllabi-or perhaps are acquired only when received as gifts.

One odd pattern was observed too late in the study to gather comprehensive data, but it is still suggestive enough to mention. A number of the works included in this study, though published as separate novels, are in effect installments in a larger work, a frequent pattern in science fiction publishing. When searching for holdings of individual titles, often double-checking by searching for author records, the author began to notice that sometimes a library would own one part of a multivolume work, but not all the parts. Because in several cases only one of the novels in a set was an award winner whose holdings had been searched, the author had in those instances only an impression of such partial holdings. In two instances, however, the data were more complete. For example, Kim Stanley Robinson's trilogy about the colonization of Mars, titled Red Mars, Green Mars, and Blue Mars, is one sustained and continuous narrative in three separately published volumes, each of which won awards as best novel.
Similarly, Gene Wolfe's celebrated Book of the New Sun was, by publisher's decision, originally released as four separate books (three of which are award winners included in the study list), though, again, it comprises one continuous narrative. In both cases, searching revealed that libraries had not acquired all the novels that form the larger work, in essence depriving readers of the complete narrative. For example, although fifty-one libraries owned all three volumes of Wolfe's Book of the New Sun included in this study, another thirty-three owned only one or two of the three. Similarly, whereas forty-three libraries owned all three of Robinson's Mars novels, another thirtyseven owned only a partial set. It should be stressed that these are not sequels in the conventional sense, in which an author revisits characters or settings that proved to be popular in the hopes of recapturing an earlier success. Instead, they are segments of a longer narrative, the individual parts of which are incomplete. This pattern suggests that ARL libraries might at times collect science fiction in a haphazard way. Possible explanations are that librarians were not familiar enough with the works selected to realize that they were incomplete without other volumes in the set or that science fiction is regarded as an occasional discretionary purchase, acquired as the budget permits and ignored when the budget is tight, or perhaps that science fiction might often be acquired as gifts, without much in the way of careful selection.

The gender of the author appears to play only a modest role in library decisions. The average ARL academic library owned 46.2 percent (or 20.8) of the fortyfive novels written by women on the list, with library holdings ranging from a mere three novels to all forty-five. On the other hand, the average library owned 51.2 percent (or 79.4) of the 155 novels written by men, with holdings ranging from 15 to 149 . Science fiction as a genre has long been a male-dominated literature (in terms of both writers and readers), 
and although this has clearly changed over the past two or three decades, male writers are somewhat more likely to be collected. On the other hand, the apparent bias in favor of male writers might simply reflect the fact that twenty-four of the forty-five novels written by women (or $53.3 \%$ ) were published in 1990 or later, a period in which ARL academic libraries appear to have slowed their acquisition of all science fiction.

A similar small effect can be seen in terms of nationality. The average ARL academic library owned 42 percent (or 18.9) of the forty-five novels by British writers (with holdings ranging from two to fortythree novels) compared to 52.4 percent (or 75.4) of the 144 novels by American writers (with holdings ranging from 11 to 141). Interestingly, the sixteen British novels in the top hundred (in terms of library holdings) were all published before 1986 (fourteen before 1980), whereas of the twenty-nine in the bottom one hundred, sixteen were published after 1990. British novels seem particularly affected by the apparent change in buying patterns after 1990. It is possible that a major factor here is that British novels without American publishers more often escape the attention of selectors. And British novels ultimately reprinted by American publishers are more likely to come to the notice of American selectors. Novels by writers of other nationalities comprise a sample far too small to support generalizations, but the average library owned 50 percent (or 3.5) of the seven Canadian novels on the list, 39.7 percent of the two Australian novels, and 72.6 percent of the three novels in the "other" category (written by a Pole, a Frenchman, and an Indian).

One factor militating against the purchase of science fiction novels by ARL libraries might be that a significant portion of science fiction is published first in paperback. Although the data on how many of the 200 novels appeared first in paperback or how many have never been published in hardcover are incomplete, one subset offers a hint of the impact of paperback publishing. The Philip K. Dick Award is given annually to the best original paperback novel. Nineteen of the Dick Award winners are included on this study's list, but only one, William Gibson's enormously popular and influential cyberpunk classic, Neuromancer (1984), is included in the top hundred novels by ARL holdings, coming in the fourteenth spot with 102 libraries owning it. The remaining eighteen are owned by an average of only fifteen of the 112 libraries checked, with seventeen ranked in the bottom fifty and eleven in the bottom twenty. This finding suggests that publication in paperback format significantly lessens the likelihood of a novel's purchase by ARL libraries. Although Gibson's Neuromancer is the evident exception, it also has been reissued in a hardcover edition, which might help to account for its somewhat anomalous popularity among ARL academic libraries. And, of course, since the Philip K. Dick Award was established only in 1982, it is unclear how much of the relative scarcity of these novels in ARL academic libraries can be attributed to format and how much to the apparent change in acquisition practices cited above. Nonetheless, it seems reasonable to suggest that ARL academic libraries are less likely to buy science fiction in paperback than in hardcover.

This study suggests that most ARL libraries do not collect science fiction extensively. Libraries tend to be strongest in the "brand name" science fiction writers and in mainstream writers who either dabble in science fiction or whose works can be claimed as science fiction. Major works of some of the most celebrated and critically acclaimed science fiction writers of the current period, such as Octavia Butler, Kim Stanley Robinson, Connie Willis, and Gene Wolfe, are owned by only half to two-thirds of the ARL academic libraries. And some of their most important books, such as Wolfe's Book of the New Sun, have been acquired in a patchwork fashion that forces readers to turn to interlibrary loan or to purchase the complete work. The study suggests that many of the ARL 
libraries have collections adequate only to support instructional needs and pleasure reading. However, there is little evidence that many will have the kind of in-depth collections to support serious research beyond studies of a relative handful of major writers and classic texts. Much of science fiction scholarship and criticism demands reading a wide range of novels (and stories), not just a few masterpieces. For example, a scholar studying racial or sexual stereotypes in science fiction or exploring how Cold War anxieties or fears of terrorism are reflected in science fiction might well want to examine dozens of novels and stories by a wide range of authors, not just a few classics. To the extent that we can extrapolate from the holdings of the relative handful of highly regarded novels in this study to the holdings of the larger body of science fiction novels published during the period, there is reason to doubt that most ARL academic libraries are able to support extensive research. As countless science fiction writers and scholars have argued, science fiction is a genre uniquely qualified to analyze and portray the impact of technology on our culture and physical environment. If science fiction continues to be studied in colleges and universities, if scholars are to be able to conduct serious research on this influential and important branch of popular culture, ARL libraries will need to consider their collection practices, committing a larger amount of their budgets and perhaps more aggressively pursuing gift collections. ${ }^{15}$
A number of related studies seem worth pursuing. Earlier discussion spoke of the desirability of studying how ARL academic libraries collect science fiction short stories and novellas, but it might be even more important to determine the extent to which they collect science fiction films and even major television series. Certainly more people habitually view science fiction films and television shows than have read even the best-known science fiction novelists, and filmed science fiction has begun to draw enormous critical attention and to exert significant cultural influence. Do ARL academic libraries have the collections to support instruction and scholarship in this area, or will scholars have to depend on their own purchases or rentals? How do collections of science fiction compare with collections of other genre fictions such as the detective story, westerns, and romances, or with formats such as comic books or graphic novels? For that matter, how do collections of science fiction compare with collections of mainstream "literary" fiction in ARL libraries? And, of course, one could extend this study beyond ARL academic libraries to consider other academic libraries and public libraries as well. Librarians have been citing the importance of developing popular culture collections for at least twenty years. ${ }^{16} \mathrm{It}$ is important to assess whether libraries are developing strong general collections in popular culture or leaving the task to a handful of special collections.

\section{Notes}

1. Arthur B. Evans and R. D. Mullen, "North American College Courses in Science Fiction, Utopian Literature, and Fantasy," Science Fiction Studies 23 (Nov. 1996): 437-528.

2. Gary Westphal and George Slusser, Science Fiction, Canonization, Marginalization, and the Academy (Westport, Conn.: Greenwood Pr., 2002); Marleen Barr, "Introduction: Textism: An Emancipation Proclamation," in "Science Fiction and Literary Studies: The Next Millennium," ed. Marleen Barr, PMLA 119 (May 2004): 429-41.

3. Hal W. Hall, Science Fiction Collections: Fantasy, Supernatural \& Weird Tales (New York: Haworth, 1983).

4. Hall, "Research Library Collections of Science Fiction" in Anatomy of Wonder: A Critical Guide to Science Fiction, 5th ed., 811-36, ed. Neil Barron (Westport, Conn.: Libraries Unlimited, 2004).

5. A list of ARL libraries is available at www.arl.org; the two academic libraries excluded are Université Laval and Université de Montréal. Stanford is included, though subsequent to the author's searching, the university decided to quit ARL. 
6. Brian M. Stableford, The Sociology of Science Fiction (San Bernadino, Calif.: Borgo Pr., 1987), 63; Gary K. Wolfe, "Evaporating Genre: Strategies of Dissolution in the Postmodern Fantastic," in Edging into the Future: Science Fiction and Contemporary Cultural Transformations, 11-29, ed. Veronica Hollinger and Joan Gordon (Philadelphia: Univ. of Pennsylvania Pr., 2002).

7. Neil Barron, "Best Books," in Anatomy of Wonder: A Critical Guide to Science Fiction, 5th ed., 837-58, ed. Neil Barron (Westport, Conn.: Libraries Unlimited, 2004); David Pringle, Science Fiction: The Hundred Best Novels, An English Language Selection, 1949-1984 (New York: Carroll \& Graf, 1985); Evans and Mullen, "North American College Courses," 525-26.

8. Hall, "Research Library Collections of Science Fiction."

9. Neil Barron, Anatomy of Wonder 4: A Critical Guide to Science Fiction, 4th ed., 455-56, ed. Neil Barron (New Providence, N.J.: R. R. Bowker, 1995). See also the online Locus Index at http://www. locusmag.com/index.

10. Hall, "Research Collections of Science Fiction," 812.

11. Ibid., 825 .

12. ARL Statistics (Washington, D.C.: ARL).

13. Evans and Mullen, "North American College Courses,"525-26; Barron, "Best Books," 838-53.

14. Edward James, "The Arthur C. Clarke Award and Its Reception in Britain," in Science Fiction, Canonization, Marginalization, and the Academy (Westport, Conn.: Greenwood Pr., 2002), 70-72.

15. Gift collections are likely to prove a valuable resource, given many readers' passionate attachment to science fiction. The author would consider himself a reader of science fiction rather than an avid collector, but his own library would rank fourteenth among the ARL libraries and it is certain that much stronger private collections abound and might ultimately be available for ARL libraries.

16. See, for example, Robert G. Sewell, "Trash or Treasure? Pop Fiction in Academic and Research Libraries," College and Research Libraries 45 (1985): 450-61; Frank W. Hoffman, Popular Culture and Libraries (Hamden, Conn.: Library Professional Publications, 1984). 